\title{
Isotope and lignin signatures in tropical peat core (Rawa Danau, Indonesia): An approach to reconstruct past vegetation and climate changes
}

\author{
Shafi M. TAREQ ${ }^{1,2}$, Noriyuki TANAKA ${ }^{3}$ and Keiichi OHTA \\ Division of Earth and Environmental Sciences, Graduate School of Environmental Studies, Nagoya University, Furo-cho, Chikusa-ku, \\ Nagoya 464-8601, Japan \\ Department of Environmental Science, Jahangirnagar University, Dhaka 1342, Bangladesh \\ Frontier Research System for Global Change, International Arctic Research Center, University of Alaska, Fairbanks, USA \\ School of Environmental Science, The University of Shiga Prefecture, 2500 Hassaka-cho, Hikone, Shiga 522-8533, Japan
}

\begin{abstract}
Peat samples from a $3.60 \mathrm{~m}$ core collected from Rawa Danau, West Java, Indonesia, were studied to reconstruct past vegetation and climate changes. The study carried out combining visual observations, elemental analyses, stable carbon and nitrogen isotope analyses as well as $\mathrm{CuO}$ oxidation of lignin residues. Variations of total organic carbon (TOC: 55.53-3.18\%, mean 23.31 $\%$ ), total nitrogen (TN: 2.52-0.06 \%, mean 0.94 $\%$ ) and water content (WC: 46.8-93.2\%, mean $79.0 \%$ ) with core lithology reflected dry and wet cycles. Vertical profiles for TOC, TN, WC and core lithology also had signatures of heavy precipitations and consequent land sliding at the abrupt change of climate (wet cycles). Variations of $(C / N)_{a}(15-93$, mean 27) and $\delta^{13} \mathrm{C}(-27.0$ to $-30.1 \%$, mean $-28.5 \%$ ) of organic matter (OM) in the peat core indicated that the organic material was comprised of terrestrial C3 plant material. The direct input of aquatic plant matter was small or overwhelmed by high terrestrial input, although changes in lake productivity due to decreasing/increasing nutrient availability were reflected in $\delta^{15} \mathrm{~N}$ profile. At low elevations in the tropical area, a large shift in vegetation zones was not likely observed. Most species might persist at the site when smallscale localized environmental changes and human disturbances or natural forest fires occurred, but the abundances of particular species might change, depending on the natural conditions in which a species could grow. However, vegetation changes associated with periodical sequence of dry and wet microenvironment were inferred from the total lignin phenol (TLP) profile.
\end{abstract}

Key words: isotope, lignin, peat, tropical, wetland, vegetation and environment

\section{INTRODUCTION}

Histosole (peat soil) contains a considerable amount of organic matter $(\mathrm{OM})$ and provides a variety of indicators that can be used to reconstruct the past depositional environment and paleoclimate (Cerling et al. 1989; Aucour et al. 1999; Müller and Voss, 1999; Choi, 2001). The types of vegetation that existed at different times in the past can also be estimated from compositions of $\mathrm{OM}$ in different age's peat layers. Tropical lowland peat deposits are often dominated by trees and shrubs (Phillips and Bustin, 1998; Wüst and Bustin, 1999). Peats from Malaysia, Indonesia, Irian Jaya and Thailand have large amounts of woody material and amorphous matrix (Wüst et al. 2001). Tropical peats are therefore rich in lignin with significant amounts of cellulose, hemicelluloses, protein and water-soluble compounds which are partially lost during early microbial activities (Orem et al. 1996; Kuder and Kruge, 1998).

A wealth of environmental and ecological information preserved in peat can often be obtained from stable isotope analyses (Rundel et al. 1989; Bowen, 1991). The natural variations in stable isotope ratios of both carbon $\left(\delta^{13} \mathrm{C}\right)$ and nitrogen $\left(\delta^{15} \mathrm{~N}\right)$ are extremely useful in tracing and quantifying sources, sinks and flux within the biogeochemical cycles (Filley et al. 2001).

In the present study, an attempt has been made to reconstruct the past vegetation and climate changes in tropical area, Rawa Danau, West Java, Indonesia, using $\delta^{13} \mathrm{C}, \delta{ }^{15} \mathrm{~N}$, atomic $(\mathrm{C} / \mathrm{N})_{\text {a }}$ ratios of $\mathrm{OM}$ together with lignin phenol composition of a peat core. The principals behind using these parameters for this purpose are; (1) significant differences of $\delta^{13} \mathrm{C}$ values in different plant types depend on photosynthetic pathway [C3 plant: $-23 \%$ o to $-34 \%$ o $(-27 \%$ ) C4 plant: $-9 \%$ to $-17 \%$ ( $-13 \%$ ) and CAM plant: $-10 \%$ to $-30 \%$; Deines, 1980; O' Leary, 1988; Farquhar et al. 1989], (2) source plant can be 
identified by lignin phenol compositions (gymnosperm plant: vanillyl phenols, angiosperm plants: vanillyl and syringyl phenols, nonwoody plant: vanillyl, syringyl and cinnamyl phenols; Hedges and Mann, 1979; Orem et al. 1997) as well as lignin enrichment of peat sample, and (3) the isotope and lignin composition of the OM in peat is similar to the isotope and lignin composition of the vegetation cover from which it derived.

\section{MATERIALS AND METHODS}

\section{Study Area}

The Rawa Danau lies in an ancient caldera of Danau volcanic complex on the north-western tip of West Java, Indonesia, at an elevation of around $100 \mathrm{~m}$ above sea level (asl), at $6^{\circ} 11^{\prime} \mathrm{S}$ and $105^{\circ} 59^{\circ} \mathrm{E}$ (Fig. 1). The catchments include the steep hills and mountains forming the wall of the caldera. The surrounding caldera rim is at an altitude about $140 \mathrm{~m}$ asl, and the adjacent high volcanic terrain is mostly between 400-700 m asl. Two hundred years ago, there was a substantial lake in the caldera and it does not exist at present as its original form (Endert, 1932). Rawa Danau occupies a few $\mathrm{km}^{2}$ and the deepest part is the crater bottom which is largely occupied by swamp. A survey of the swamp deposit by Indonesia Geological Survey (IGS) shows that deeper basin deposits (> $6 \mathrm{~m}$ depth) consist of fine-grains (organic silt-clay) with minor intercalations of peat and fluvial sands (Rimbaman, 1994). Peat deposits prevail in the central swamp area with sequences up to $4-5 \mathrm{~m}$ thickness just below the surface.

Climate of the Java Island in Indonesia is driven by the Asian monsoon system. Van Steenis (1965) documented a pronounced floristic gradient across the island correlated with the change in climate. The main vegetation types of Rawa Danau are mixed forest swamp, Ficus retusa swamp forest, open herbaceous swamp and dry land largely deciduous (Stujts, 1993; Kaars et al., 2001; references therein). The swamp vegetation in the northern part is partially replaced by rice field, but the signature of original swamp forest is still common at the edge of remaining fresh water swamp.

\section{Sampling}

After analyzing three test cores from Rawa Danau, the main core (RD-1), $360 \mathrm{~cm}$ deep and $10 \mathrm{~cm}$ diameter, was collected by piston coring in September 2001. Since piston coring disturbed upper portion of the main core, a gravity sub-core of $32 \mathrm{~cm}$ was collected to maintain sedimentary sequence. The peat cores were divided into slice approx. $2 \mathrm{~cm}$ thick, sealed in polyethylene bag and transported to laboratory. The material was freeze-dried, homogenized with mortar and pestle, passed through a $300 \mu \mathrm{m}$ sieve and finally preserved for subsequent analysis.

\section{Elemental and Isotopic Analyses}

The water content (WC) was determined gravimetrically using weight differences between wet and dried samples and expressed in \%. Weight percentage of total organic carbon (TOC) and total nitrogen (TN) were measured by Thermo Quest elemental analyzer of model NA2500 NCS. Samples were combusted at $1000^{\circ} \mathrm{C}$ to $\mathrm{CO}_{2}$ and $\mathrm{NO}_{\mathrm{x}}$ gas and a subsequent $\mathrm{Cu}$-packed column reduced

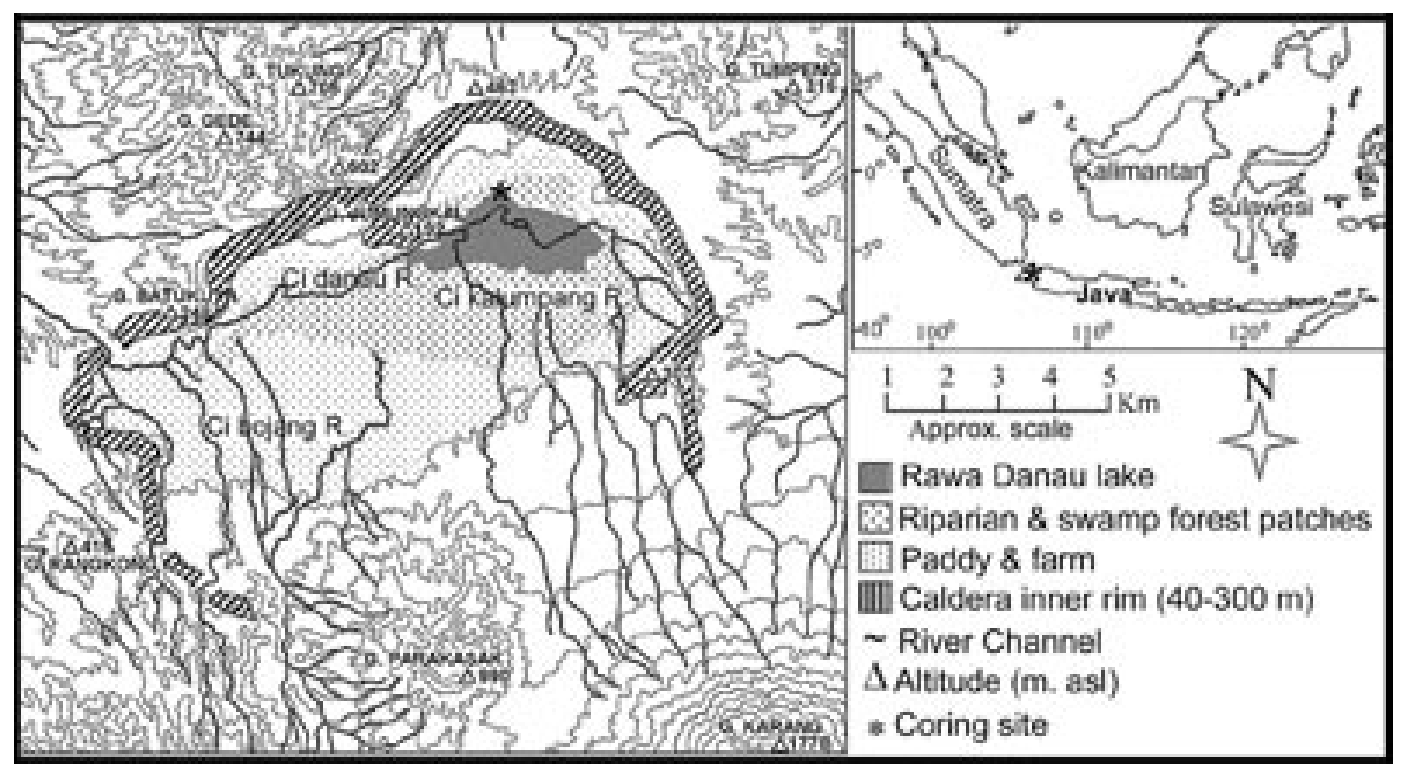

Fig. 1. Map of the coring site. (after Tareq et al. 2004) 
$\mathrm{NO}_{\mathrm{x}}$ to $\mathrm{N}_{2}$ gas at $750^{\circ} \mathrm{C}$. Alanine was used as a standard for TOC and TN determination. A few selected samples run several times for estimating the reproducibility of the measurements and found that the deviation is less than $\pm 5 \%$ for both TOC and TN.

Stable carbon and nitrogen isotope compositions were determined by the method involving automatic combustion in a elemental analyzer (Thermo Quest NA 2500 NCS) interfaced via a Finnigan CONFLOW II system to a Finnigan MAT 252 mass spectrometer (Finnigan, 1995). Half the samples were analyzed at least in duplicate with a maximum difference of $\pm 0.2 \%$ between replicates. The performance of the automatic EA-CONFLOW II - MS system was evaluated by running the working standard alanine samples of known $\delta{ }^{13} \mathrm{C}$ $(-21.56 \%)$ and $\delta^{15} \mathrm{~N}(-5.25 \%)$ values and the accepted values were obtained for both of carbon $( \pm 0.07 \%$ ) and nitrogen $( \pm 0.21 \%$ ) within samples size ranges $7-100 \mu \mathrm{g}$ carbon and 100-300 $\mu \mathrm{g}$ nitrogen for the measurements.

\section{Lignin Phenol Analysis}

About $30 \mathrm{mg}$ of bulk lipid free peat was oxidized with $\mathrm{CuO}$ at $170^{\circ} \mathrm{C}$ for 3 hours in $2 \mathrm{~N} \mathrm{NaOH}$ containing ferrous ammonium sulfate $\left[\mathrm{Fe}\left(\mathrm{NH}_{4}\right)_{2}\left(\mathrm{SO}_{4}\right)_{2} \cdot 6 \mathrm{H}_{2} \mathrm{O}\right]$ (Hedges and Ertel, 1982). After adding known amount of ethylvanillin as internal standards and adjusting the $\mathrm{pH}$ tol by adding $6 \mathrm{~N} \mathrm{HCl}$, lignin phenols were extracted with peroxidefree diethylether. The quantification of lignin phenol monomers were performed by GC (Shimadzu14B) equipped with DB-1 (60 m $\times 0.25 \mathrm{~mm}$, i.d.). Details of the procedures were described elsewhere (Tareq et al.
2004).

\section{RESULTS AND DISCUSSION}

\section{Core Lithology and Sedimentation Rate}

The core (RD-1) of $360 \mathrm{~cm}$ in total length collected by $380 \mathrm{~cm}$ core tube insertion indicated only less than $5 \%$ compaction during coring operation. The upper $50 \mathrm{~cm}$ of the core was a mixture of grass-woody peat and partially decayed plant tissues except for the depths of 8-12 cm that were enriched by silty-sand-clay. Visual inspection during sample processing indicated that rest of the core (50-360 cm) was mainly composed of woody peat. A few numbers of silty-sand-clay enriched layers were detected at different depths $(9,115,175,225$, and $280 \mathrm{~cm})$. Perhaps, these silty-sand-clay layers are the signature of upper mountainous erosion due to heavy precipitation or changing water level of the lake. No decreasing trend with depth was observed in water content (WC) profile, rather it was correlated with core lithology, TOC and $\mathrm{TN}$ as shown in Fig. 2. It was also clear from the WC profile that compaction effect was not pronounced during sedimentation.

Nine conventional radiocarbon $\left({ }^{14} \mathrm{C}\right)$ dates on bulk sediment are available for the core $\mathrm{RD}-1$ sequence. The ${ }^{14} \mathrm{C}$ analysis was carried out by Dr. Darwin Siregar (personal communication) in the Geological Research Development Center, Indonesia, according to the acetylene counting method using a gas proportional counter. We calibrated the ${ }^{14} \mathrm{C}$ dates by CALIB rev. 4.3 (Stuvier at al., 1998), and the results were listed in Table 1. The organic matter preserved at the bottom section of

Table 1. Calibrated radiocarbon ages* of the core RD-1.

\begin{tabular}{|c|c|c|c|c|c|c|}
\hline \multirow{2}{*}{$\begin{array}{l}\text { Sample } \\
\text { code }\end{array}$} & \multirow{2}{*}{$\begin{array}{l}\text { Depth } \\
(\mathrm{cm})\end{array}$} & \multirow{2}{*}{$\begin{array}{l}\text { Uncalibrated } \\
{ }^{14} \text { Cage } \pm \text { SD } \\
\text { (BP) }\end{array}$} & \multicolumn{2}{|c|}{ Cal. Age in BP } & \multicolumn{2}{|c|}{ Cal. Age in $\mathrm{AD} / \mathrm{BC}$} \\
\hline & & & $(1 \sigma)$ & $(2 \sigma)$ & $(1 \sigma)$ & $(2 \sigma)$ \\
\hline RDT2 & 22 & $410 \pm 240$ & $423(0.78)$ & 353 & $\mathrm{AD} 1527(0.78)$ & $\mathrm{AD} 1600$ \\
\hline RDT3 & 55.5 & $880 \pm 220$ & $820(0.94)$ & $858(0.97)$ & $\mathrm{AD} 1130(0.94)$ & $\mathrm{AD} 1098(0.97)$ \\
\hline RDT4 & 66.9 & $1040 \pm 280$ & 954 (0.93) & $974(0.98)$ & AD 996 (0.93) & $\mathrm{AD} 976(0.98)$ \\
\hline RDT5 & 99 & $1400 \pm 260$ & $1305(0.95)$ & 1310 & $\mathrm{AD} 645$ (0.95) & $\mathrm{AD} 640$ \\
\hline RDT6 & 123.2 & $1600 \pm 290$ & $1547(0.97)$ & 1548 & $\mathrm{AD} 404(0.97)$ & $\mathrm{AD} 402$ \\
\hline RDT7 & 137.6 & $1740 \pm 350$ & 1672 & 1704 & AD 278 & $\mathrm{AD} 246$ \\
\hline $\mathrm{RDB} 1$ & 175.3 & $3030 \pm 260$ & 3169 & $3287(0.98)$ & BC 1220 & BC $1338(0.98)$ \\
\hline $\mathrm{RDB} 2$ & 188.3 & $3500 \pm 360$ & $3813(0.98)$ & $3800(0.98)$ & BC $1861(0.98)$ & BC $1851(0.98)$ \\
\hline RDB3 & 207.7 & $4020 \pm 360$ & $4429(0.96)$ & $4455(0.97)$ & BC $2480(0.96)$ & BC 2506 (0.97) \\
\hline Bottom & 360 & - & $7428^{* *}$ & 7428 & BC 5479 & BC 5479 \\
\hline
\end{tabular}

*Ages are calibrated in both years B. P. and A.D./B.C., and expressed at one sigma (68.3\% confidence) and two sigma (95.4\% confidence) ranges. Where multiple intersections of the calibration curve occur, the largest relative area of the probability distribution in each case was chosen to represent the most probable age range (probability values shown in brackets and italicized). Age values are meadian age of the two sigma calibrated ranges.

${ }^{* *}$ Age is estimated from the depth-age relationship found for upper sediment layers, assuming a constant accumulation rate. 
the core represented Holocene materials (7.4 ka BP). The low accumulation rate observed after $1.7 \mathrm{ka}$ BP made the interpolated ages somewhat uncertain in comparison to the much better resolution of the overlying sections.

\section{Distribution of Organic Carbon and Nitrogen}

The TOC content remained high throughout the all depths with some sharp peaks at different depths as usually observed for the accumulation of OM from terrestrial sources (Aucour et al. 1999; Bourdon et al. 2000, references therein). A vertical profile of TOC showed variation between 3.2 and $55.5 \%$ with an average

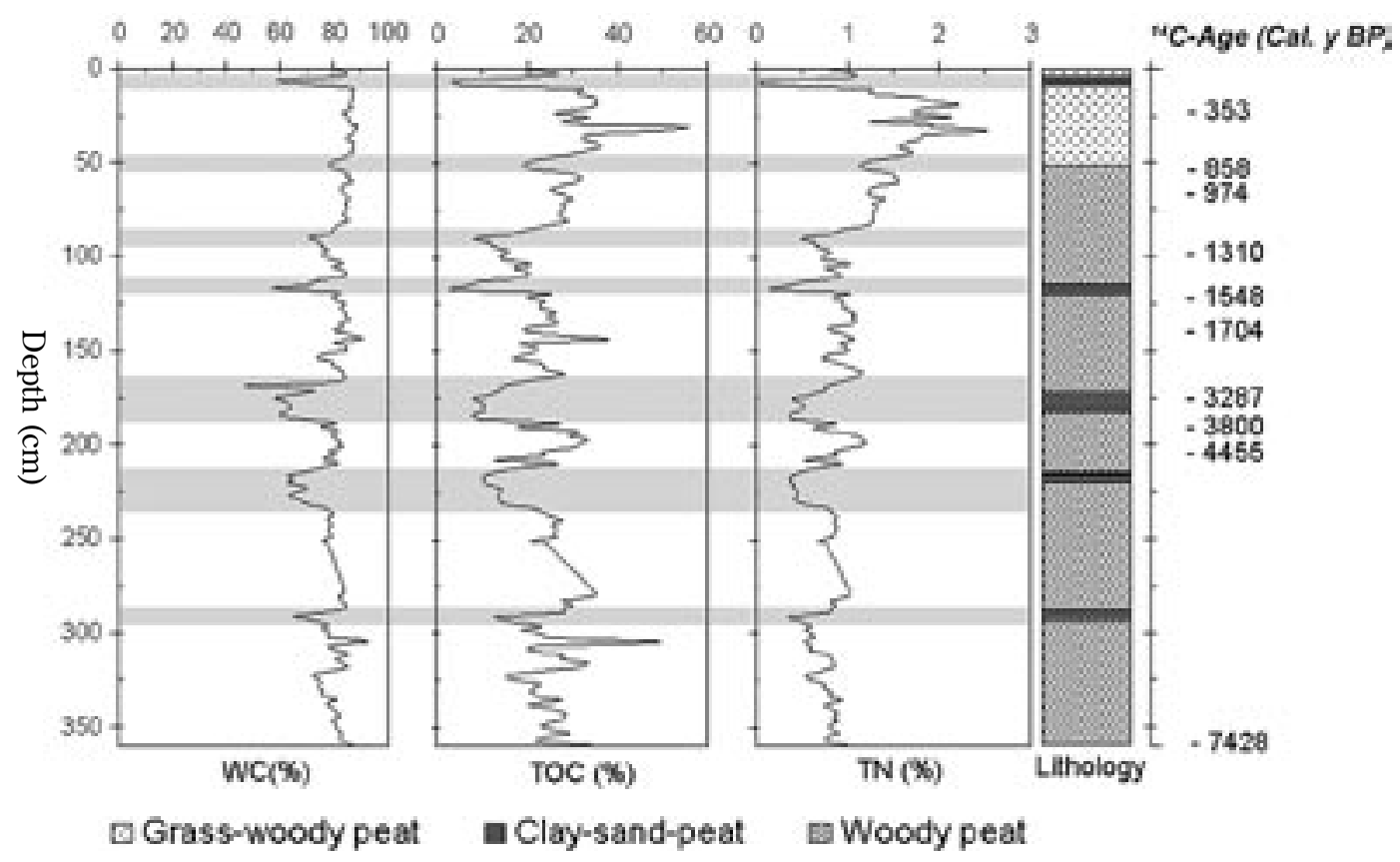

Fig. 2. Vertical distributions of total organic carbon (TOC), total nitrogen (TN) and water content (WC) with calibrated ${ }^{14} \mathrm{C}$-age. Shaded area indicates different hydrological regimes.

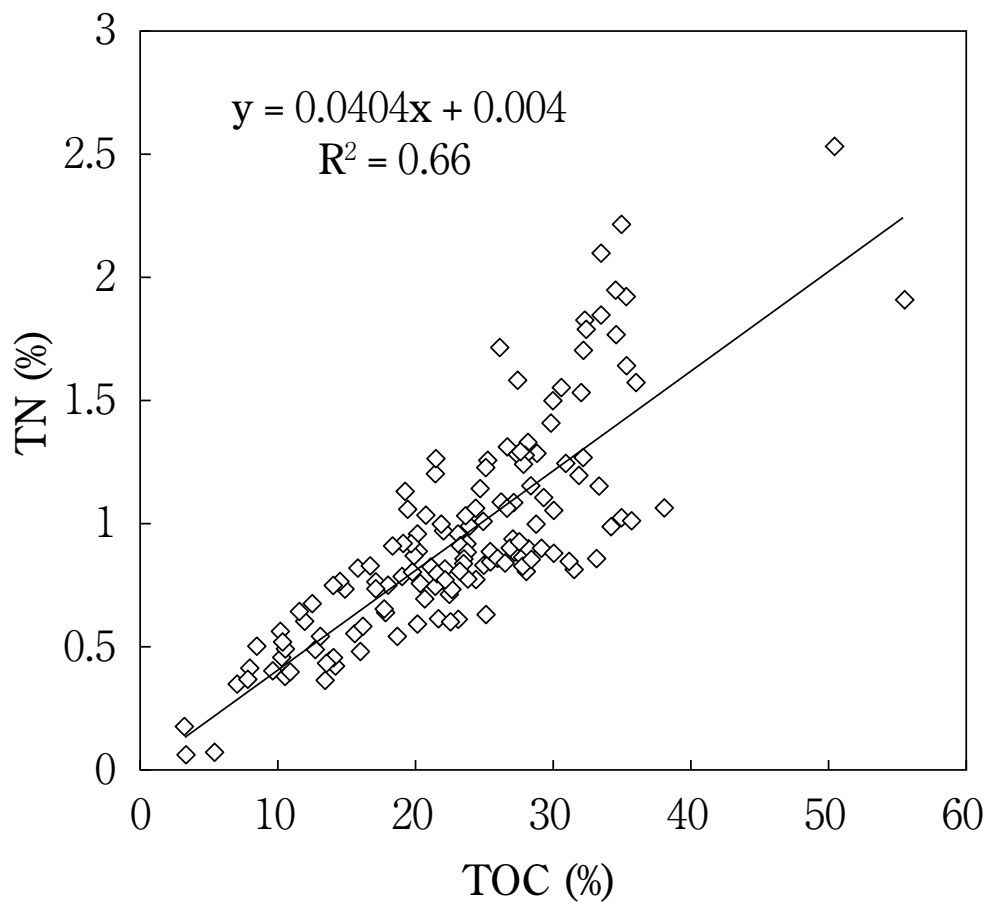

Fig. 3. Correlation between TOC and TN of the RD-1 core. 
of $23.3 \%$.

The vertical distribution of total nitrogen (TN) with depth of peat core is shown in Fig. 2. The TN ranged from 0.06 to $2.52 \%$ with an average value $0.94 \%$ for overall the depths. In relation to TOC content, TN also showed peaks at the same depths. There was a significant correlation (Fig. 3; $r^{2}=0.66$ ) between TOC and TN which could be attributed to the possible unique source signature overall the accumulation period. Both TOC and TN contents were higher in woody peat layer than the clay-silt-sand enriched layers.

The atomic ratios of carbon to nitrogen $(\mathrm{C} / \mathrm{N})_{\mathrm{a}}$ varied frequently (15-93) with an average value 27 . The $(\mathrm{C} / \mathrm{N})_{\mathrm{a}}$ ratio is widely used to identify the source of OM (Meyers, 1994; Herczeg et al., 2001). Vascular land plant has C/N ratios higher than $20(\mathrm{C} / \mathrm{N}>20)$ due to comparatively high cellulose content whereas non-vascular sources like algae and phytoplankton have $\mathrm{C} / \mathrm{N}$ ratios from 4 to 10 (Meyers, 1997). Most of the layers of core RD-1 had (C/ $\mathrm{N})_{\mathrm{a}}>20$ indicating vascular plant sources, but few layers at different depths had $(\mathrm{C} / \mathrm{N})_{\text {a }} \quad 20-10$ due to complex heterogeneous contributions of the terrestrial plant sources and in-situ developed aquatic species such as algae, phytoplankton, and other protein enriched sources under an optimized environmental condition.

The $\delta^{13} \mathrm{C}, \delta^{15} \mathrm{~N}$ and $(\mathrm{C} / \mathrm{N})_{\mathrm{a}}$ values for the whole core are plotted versus depth in Fig. 4 along with calibrated time scale for the $7.4 \mathrm{ka} \mathrm{BP}\left({ }^{14} \mathrm{C}\right.$ age). The $\delta^{13} \mathrm{C}$ displayed a small range of fluctuation between -27.0 and -30.1 $\%$. This shift apparently should be caused at least by selective loss of the isotopically heavy carbohydrate fraction (compare to lignin) of total OM (Spiker and Hatcher, 1984). Diagenetic effect usually induces minor $\delta^{13} \mathrm{C}$ depletion in buried OM ( $>2 \%$; Macko et al., 1991; Meyers, 1994) and can be considered as a secondary factor for the observed variability.

The average values of $\delta^{13} \mathrm{C}(-27.2 \%)$ and $\mathrm{C} / \mathrm{N}$ ratio (27) is a signature of the dominance of $\mathrm{C} 3$ terrestrial plants though the isotopic signature of C3 land plants can not be distinguished from that of fresh water algae (Meyers, 1994). The natural difference in stable carbon isotope ratio of different plants provides fine resolution spectrum of vegetation succession in tropical wetland (Chmura et al. 1987; DeLaune, 1986) and has the potential to provide valuable evidence of changing hydrological regime and climate. In Rawa Danau, the vegetation was not completely altered during peat development, but only relative abundances of different plant species (angiosperm, gymnosperm, nonwoody plants) changed as was shown by lignin phenol compositions (Tareq et al. 2004).

The irregular changes of $\delta^{13} \mathrm{C}$ values at different depths were more likely due to isotopic fractionation in changing relevant climatic parameters including precipitation and air temperature. Stewart et al. (1995) suggested a co-efficient for eastern Australian climate covering a large range of precipitation (350-1500 mm) and open vegetation. The variation of $\delta^{13} \mathrm{C}$ in the peat core reflects the changes water availability results in a complex balance among precipitation, annual distribution,
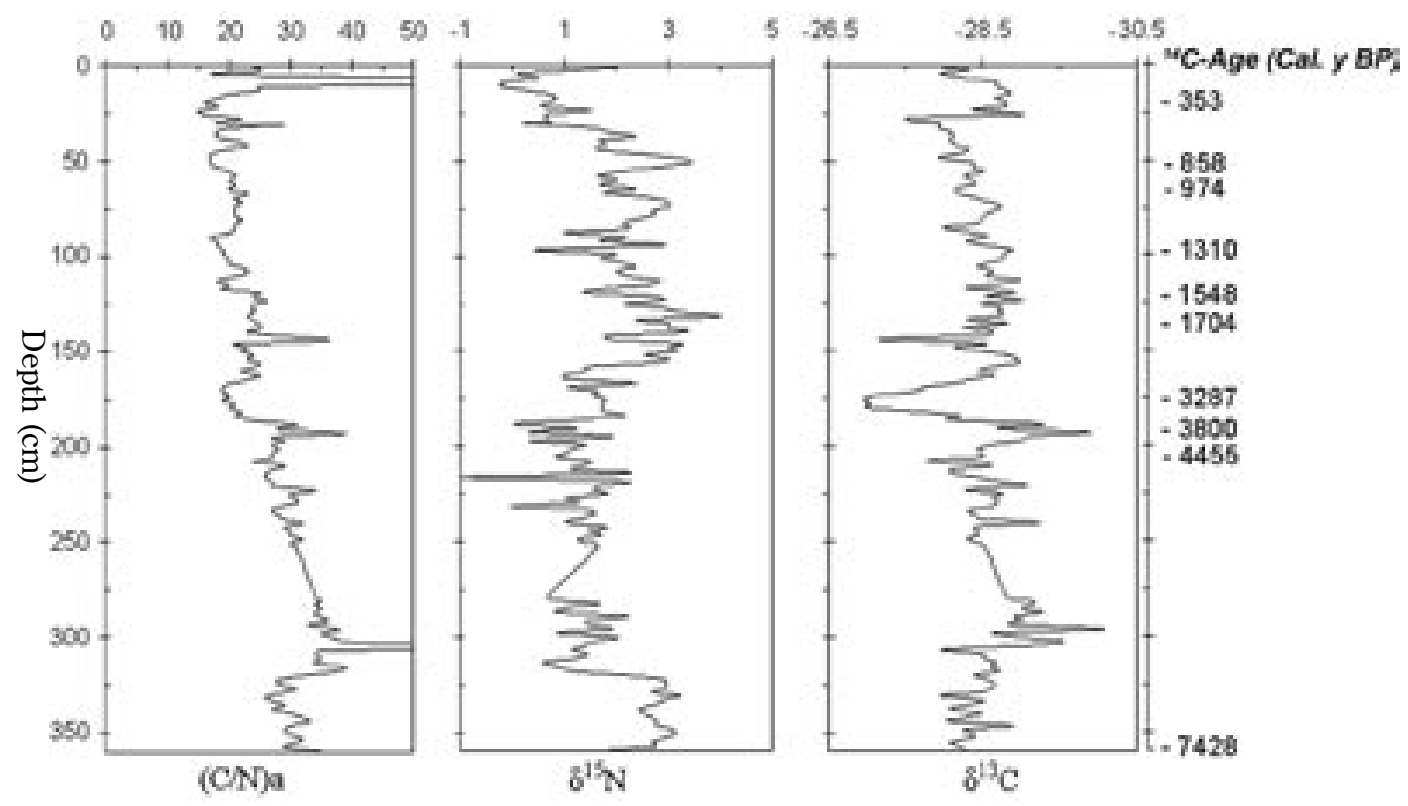

Fig. 4. Vertical profiles of $(\mathrm{C} / \mathrm{N}) \mathrm{a}, \delta^{13} \mathrm{C}, \delta^{15} \mathrm{~N}$ with calibrated radiocarbon age. 


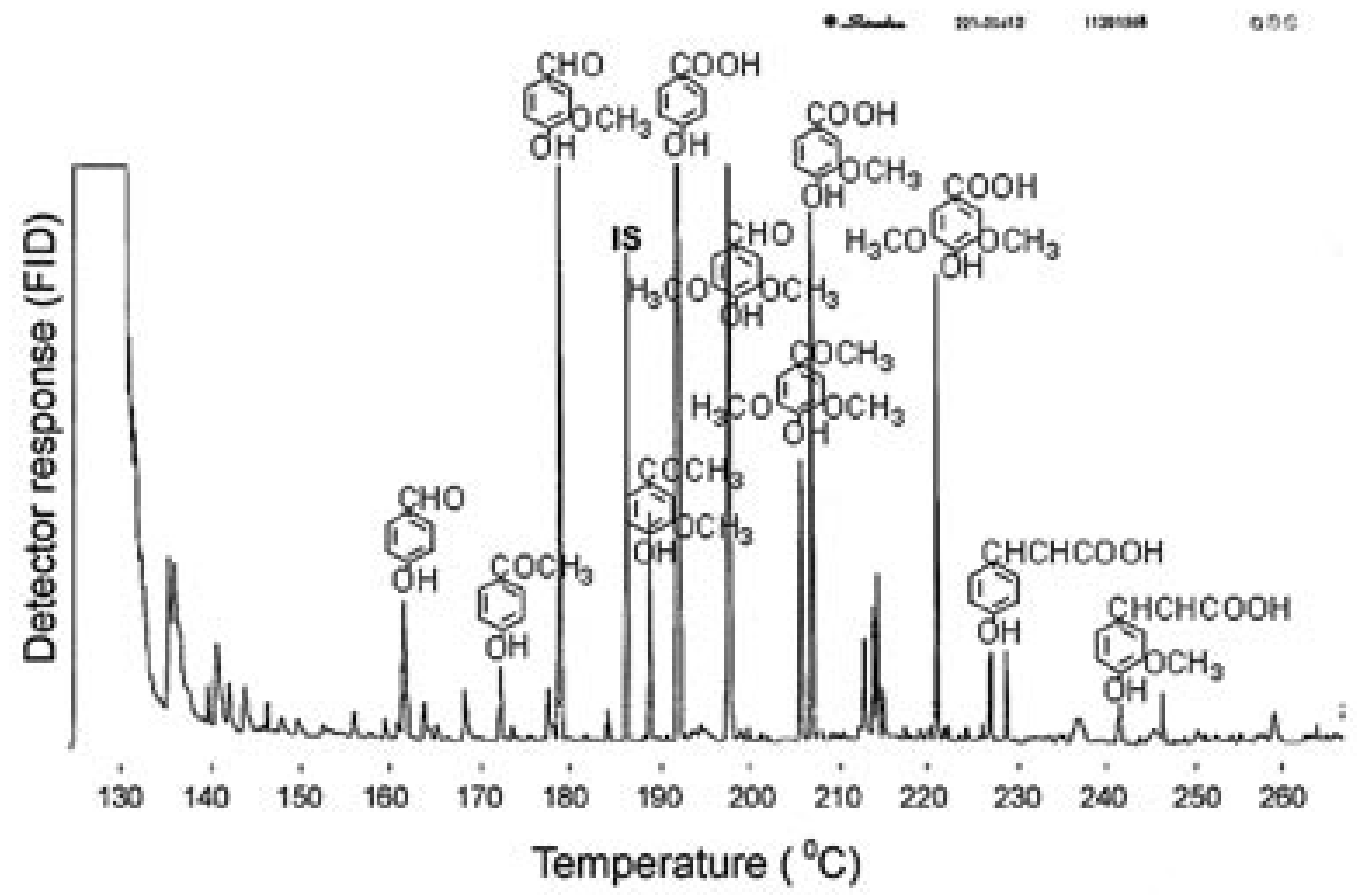

Fig. 5. A representative gas chromatograph of lignin-TMS, GC condition: DB-1 (60 m $\times 0.25 \mathrm{~mm} \mathrm{i.d.),} 120^{\circ} \mathrm{C}$ to $290^{\circ} \mathrm{C}$ at the rate of $2^{\circ} / \mathrm{min}$, ethylvanillin used as GC internal standard.

TLP in peat (mg/g ds)

$\begin{array}{llllllll}0 & 20 & 40 & 60 & 80 & 100 & 120\end{array}$

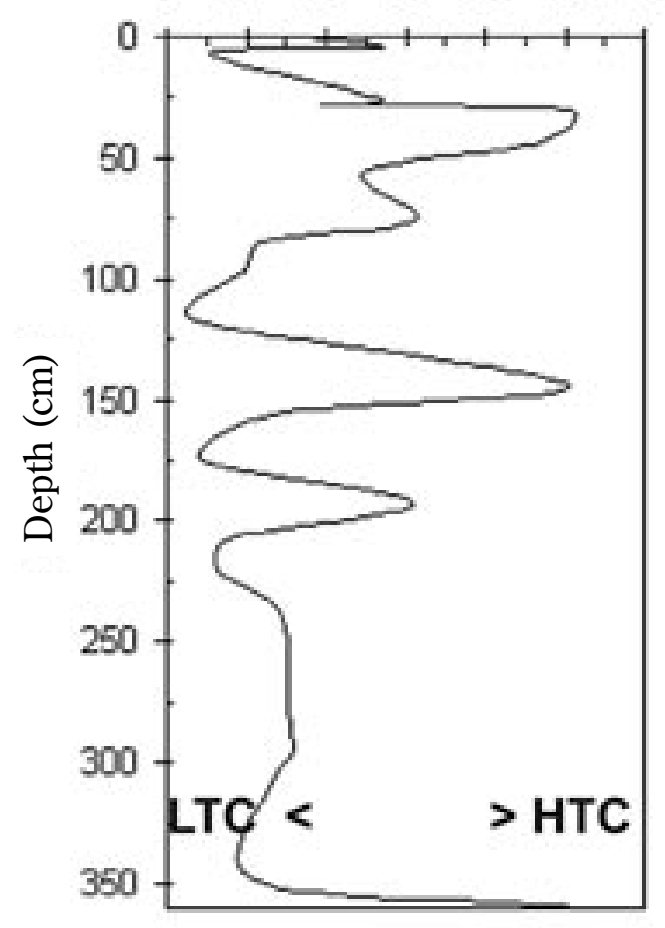

Fig. 6. Vertical distribution of total lignin phenols (TLP in $\mathrm{mg} / \mathrm{g}$ dry peat) of the core RD-1. LTC: Low terrestrial contribution; HTC: High terrestrial contribution evaporation, water runoff and drainage.

The elemental carbon record indicated frequent forest fire from mid-late Holocene and $\delta{ }^{13} \mathrm{C}$-elemental carbon showed a positive correlation with $\delta{ }^{13} \mathrm{C}$-TOC (Tareq et al. 2005). The forest fire events documented by the elemental carbon record concur with dry climatic conditions of periodical wet and dry cycles (as shown in Fig. 2). It can be postulated that the local climate has been influenced by long term variations of $\mathrm{El} \mathrm{Niño/}$ Southern Oscillation (ENSO) as we observed for last few decades in tropical zone.

\section{Nitrogen Isotopic Signature}

Variation of $\delta^{15} \mathrm{~N}$ values of peat core RD-1 was between -1.0 and $4.0 \%$ with mean of $2.0 \%$, indicating the change in composition of source materials and relevant environmental parameters. Algal and land plant sources of OM have distinct values of $\delta^{15} \mathrm{~N}$ due to the different isotopic composition of inorganic nitrogen taken by aquatic and land plants. Hydrological changes can also affect the $\delta^{15} \mathrm{~N}$ value of peat of the tropical wetland. Meyers et al. (1998) noted a $2 \%$ shift towards higher values due to lowering of the water level in Pyramid lake, Nevada, that was caused by partial diversion of Truckee river for agricultural use.

The major rivers in Rawa Danau shifted several times artificially and/or naturally, and it might play 
an important role on shifting the $\delta^{15} \mathrm{~N}$ values. The chronological information derived from ${ }^{14} \mathrm{C}$ indicated that the enrichment of $\delta^{15} \mathrm{~N}$ in the peat core began in mid Holocene when the lake became shallow (From diatom records; Kaars et al. 2001) and $\delta^{15} \mathrm{~N}$ was depleted again from the late Holocene. Vertical profile of $\delta^{15} \mathrm{~N}$ should reflect changing in aquatic productivity of the wetland.

\section{Lignin Signature}

A representative gas chromatogram of the $\mathrm{CuO}$ oxidation products of Rawa Danau peat shows in Fig. 5. Eleven lignin phenol monomers (p-hydroxybenzoic, vanillyl, syringyl and cinnamyl phenols) were determined among $\mathrm{CuO}$ oxidation products of 24 pre-selected samples. Vanillic phenols are derived from the coniferyl lignin and both vanillic and syringic phenols are from sinapyl moieties of lignin. They consist of aldehydes, ketones and acids. The p-coumaric and ferulic acids (cinnamic unit) linked to cellulose by ester bonds are generated from the cinnamyl alcohol-derived moieties. p-Hydroxybenzoic phenols were also determined, but this group can be partly derived from other sources than lignin (Hedges and Parker, 1976; Hedges and Ertel, 1982). Total lignin phenol (TLP) in $\mathrm{mg} / \mathrm{g}$ dry peat is calculated as the sum of the four groups (p-hydroxybenzoic, vanillyl, syringyl and cinnamyl phenols).

Total lignin phenol (TLP) concentrations of peat core (RD-1) from Rawa Danau were generally higher than those from other sediments and more comparable to those observed in other tropical peat land (Bourdon et al., 2000). The high concentrations of TLP reflect high vascular plant contribution to the wetland in Rawa Danau as suggested by the high atomic $(\mathrm{C} / \mathrm{N})_{\mathrm{a}}$ ratio.
The vertical distribution of TLP of the core RD-1 (Fig. 6) showed increasing vascular plant component in $\mathrm{OM}$ at the calibrated age of 1, 1.5, 3.5, 4.5 and $7.4 \mathrm{ka}$ BP. However, this pattern can be influenced by rapid sedimentation and selective degradation of lignin under oxic conditions. It can be inferred from alternative variations of TLP that the terrestrial vegetation of Rawa Danau strongly influenced by the hydrological changed as indicated in Fig. 2 . The detail of the vegetation change history is discussed else where (Tareq et al. 2004) depending on composition of lignin monomers and newly defined lignin phenol vegetation index (LPVI).

We also analyzed $\mathrm{CuO}$ oxidation lignin monomers of the four most dominated plant species (Polypodiaceace, Cyperaceae, Pandanus and Gramina) around the coring site. The materials from the living plants showed high lignin contents comparable to the value previously obtained for tropical nonwoody plants (Bourdon et al., 2000). The cinnamic group composed of both p-coumaric and ferluic acid dominated (Table 2). By comparison with fresh plants, small fraction of cinnamic phenols was found in the surface of the wetland (Table 2) and the amount of lignin substantially decreased, indicating post-depositional diagenetic loss of cinnamic group is higher than that of syringic and vanillic groups. The loss of cinnamyl phenols can be attributed to early diagenetic nature of cellulose ester bonds and thus $\mathrm{C} / \mathrm{V}$ ratio can be used as indicator of degree of early diagenesis of $\mathrm{OM}$ in wetland.

A comparison of average values of lignin phenol parameters between fresh plants and the surface peat is illustrated in Fig. 7. In every phenol family, peat yielded less aldehyde and proportionately more acid than fresh plant tissues did. These compositional differences are

Table 2. Lignin phenol composition ( $\mathrm{mg} / \mathrm{g}$ of dry samples) of the plant samples collected from coring site and relevant lignin parameters with mean values of surface peat.

\begin{tabular}{|c|c|c|c|c|c|c|c|c|c|c|c|c|c|}
\hline $\begin{array}{c}\text { Name } \\
\text { of species }\end{array}$ & $\% \mathrm{OC}$ & $\mathrm{p}-\mathrm{Hg}$ & $\mathrm{Vg}$ & $\mathrm{Sg}$ & $\mathrm{Cg}$ & $\mathrm{S} / \mathrm{V}$ & $\mathrm{C} / \mathrm{V}$ & $\mathrm{p}-\mathrm{H} / \mathrm{V}$ & $(\mathrm{Ad} / \mathrm{Al})_{\mathrm{v}}$ & $(\mathrm{Ad} / \mathrm{Al})_{\mathrm{s}}$ & $(\mathrm{Ad} / \mathrm{Al})_{\mathrm{pH}}$ & TLP & $\lambda_{8}$ \\
\hline Polypodiaceac & 41.1 & 8.2 & 11.3 & 12.7 & 6.5 & 1.12 & 0.58 & 0.73 & 0.27 & 0.25 & 0.22 & 38.7 & 7.4 \\
\hline Pandanus & 43.3 & 17.3 & 7.2 & 10.1 & 6.0 & 1.4 & 0.83 & 2.4 & 0.26 & 0.23 & 0.25 & 40.6 & 5.4 \\
\hline Cyperaceae & 42.1 & 12.2 & 17.0 & 20.0 & 10.6 & 1.2 & 0.62 & 0.72 & 0.20 & 0.25 & 0.37 & 59.8 & 11.3 \\
\hline Gramina & 41.5 & 10.5 & 10.3 & 18.2 & 8.6 & 1.8 & 0.83 & 1.02 & 0.26 & 0.20 & 0.38 & 47.6 & 9.0 \\
\hline $\begin{array}{c}\text { Average } \\
\text { (plants) }\end{array}$ & 42.0 & 12.5 & 11.5 & 15.3 & 7.9 & 1.4 & 0.72 & 1.22 & 0.25 & 20 & 0.30 & 46.7 & 8.3 \\
\hline$\pm \mathrm{SD}$ & \pm 0.84 & \pm 3.35 & \pm 3.54 & \pm 4.01 & \pm 1.83 & \pm 0.25 & \pm 0.12 & \pm 0.70 & \pm 0.03 & \pm 0.02 & \pm 0.07 & \pm 8.27 & \pm 2.2 \\
\hline $\begin{array}{c}\text { Average } \\
\text { (surface } \\
\text { peat) }\end{array}$ & 26.4 & 11.3 & 16.3 & 15.8 & 2.1 & 1.03 & 0.13 & 0.73 & 0.52 & 1.28 & 0.37 & 45.5 & 14.0 \\
\hline$\pm \mathrm{SD}$ & \pm 7.73 & \pm 1.70 & \pm 4.73 & \pm 1.72 & \pm 0.42 & \pm 0.24 & \pm 0.03 & \pm 0.15 & \pm 0.18 & \pm 0.40 & \pm 0.15 & \pm 8.11 & \pm 4.6 \\
\hline
\end{tabular}

Abbreviations: OC: organic carbon, p-Hg: p-hydroxybenzoic group, Vg: vanillyl group, Sg: syringyl group, Cg: cinnamyl group, (Ad/Al): acid/ aldehyde, TLP: total lignin phenols in $\mathrm{mg} / \mathrm{g}$ dry peat, $\lambda_{8}$ (lamda): sum of vanillyl, syringyl and cinnamyl phenols per $100 \mathrm{mg}$ organic carbon 


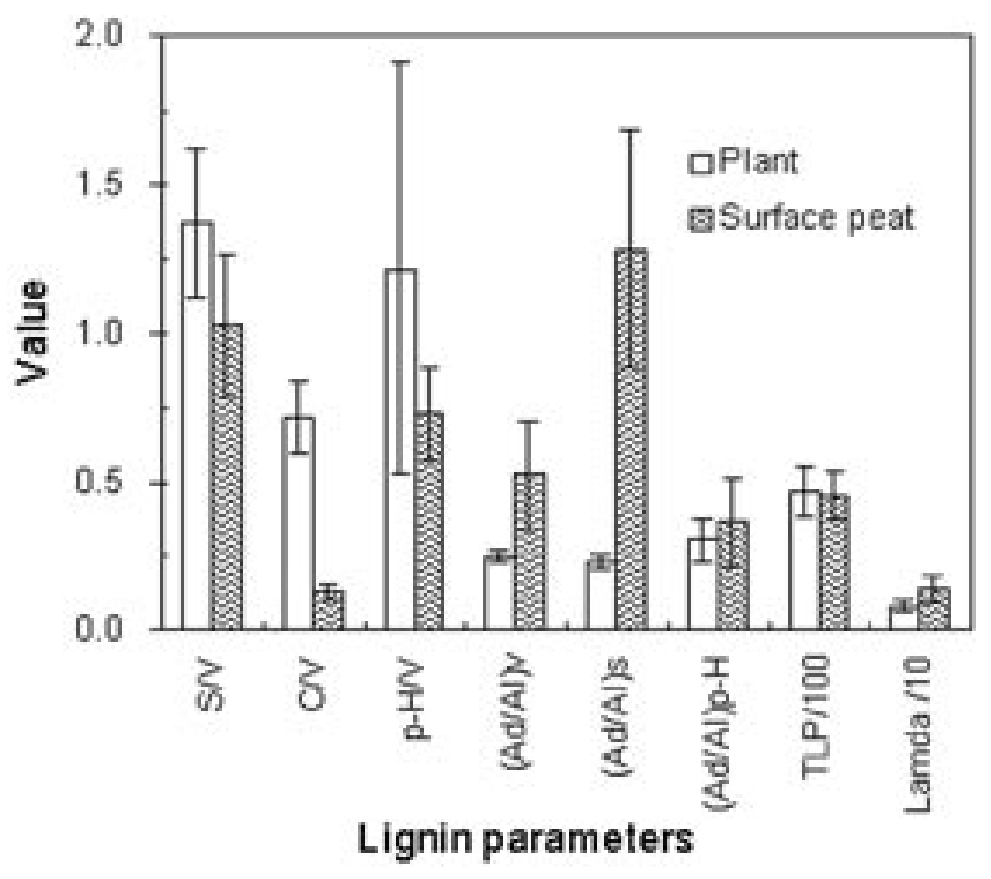

Fig. 7. Bar chart of the mean of the lignin parameters of four living plants and surface peat of Rawa Danau (Vertical bars represents \pm SD).

sensitively reflecting the post depositional oxidatative degradation of lignin. Comparison of lignin phenol ratio parameters $(\mathrm{S} / \mathrm{V}, \mathrm{C} / \mathrm{V}$ and $\mathrm{p}-\mathrm{H} / \mathrm{V})$ between fresh plants and surface peat concurred with the results of earlier discussion on the rate of post-depositional diagenetic loss (cinnamic $>$ syringic $>$ vanillic). Average values of TLP and $\lambda_{8}$ ( $\sum$ vanillic, syringic, and cinnamic in $\mathrm{mg} / 100 \mathrm{mg}$ OC) of peat are higher than those of fresh plants due to early diagenetic loss of non-lignin components of OM in the tropical wetland.

\section{Human Dimension and Environment}

Vegetation in a landscape can be disturbed by both of human activities and environmental changes. At a glance, the vegetation in Rawa Danau is apparently remained constant during Holocene, in which relative abundances of different species are established as a function of local topography, hydrology and climate. Anthropogenic disturbances are dominated by human social and economic processes and are more variable than natural disturbances. Charcoal is commonly present in tropical rainforest soils (Sanford et al. 1985; Saldarriaga and West, 1986). However, the implications of these data are unclear because we do not know whether the charcoal was produced by natural forest fires or by human activities.

People clearly had a large impact on the vegetation development in Rawa Danau area during the last few hundred years as evidenced by increased burning, the appearance of food crops, the apparent opening of the vegetation with many grasses, sedges and ferns and presence of weeds (Kaars et al. 2001). Once the vegetation is disturbed by human impact and/or natural forest fire, the original forest is usually replaced by grasses and sedges with occasional shrub or trees. The pollen data suggested that the vegetation of Rawa Danau wetland dominated by angiosperms, and few sections have signatures of relatively high abundance of nonwwody plants (e.g., grasses), especially at $0-50 \mathrm{~cm}$ and $150-200 \mathrm{~cm}$ depths (Yulianto et al. 2005). However, lignin phenols compositions reflected the presence of gymnosperm $(\mathrm{S} / \mathrm{V}<0.60)$ during forest fire events (Tareq et al. 2004). The gymnosperm lignin signature would most probably be attributed to the expansion of nonwoody gymnosperm plants, e.g., ferns which might predominate over grasses during vegetation succession in tropical wetlands, although Yulianto et al. (2005) did not describe in detail the distribution of fern spores.

It is quite difficult to distinguish between the human dimension and climate forcing on the vegetation changes at mid Holocene time (during 3.5-7.4 ka BP). Large scale vegetation changes/intensive forest fire occurred during 3.8-4.5 ka BP, but our data were unable to identify whether that changes caused by human dimension (through forest clearance or burning) or natural climatic changes (i.e., drought). But it is clear from our records that the recent vegetation changes/forest fires were caused by human activities that enhanced the periodical ENSO events.

\section{CONCLUSIONS}

Variations of $(\mathrm{C} / \mathrm{N})_{a}, \delta{ }^{13} \mathrm{C}$ and $\delta^{15} \mathrm{~N}$ of $\mathrm{OM}$ in the peat core indicated that the organic material was comprised of terrestrial C3 plant material, and the direct input of aquatic plant matter was small or overwhelmed by high terrestrial input. Excursions in the isotopic abundances of $5 \%$ in $\delta^{15} \mathrm{~N}$ and $-3.1 \%$ in $\delta^{13} \mathrm{C}$ are not artifacts of diagenetic processes but were caused by changes in sources of organic matter. Although, it was difficult from small scale excursion of stable isotope values to 
identify paleovegetation and environmental changes, lignin phenols together with other geochemical data (like elemental carbon, TOC, $\delta^{13} \mathrm{C}$ ) were able to indicate small scale shift of terrestrial vegetations. The TLP concentrations of core $\mathrm{RD}-1$ varied with depth due to the changes in composition of terrestrial plant of Rawa Danau in response to climate changes.

ACKNOWLEDGEMENTS We are grateful to Japanese Ministry of Education, Culture, Sports, Science and Technology and Hori Information Science Promotion Foundation for financial support for this study. We also wish to thanks Hokkaido University for providing travel support to present this paper in International Symposium on Land Management and Biodiversity in Southeast Asia, Bali, Indonesia, September, 2002.

\section{REFERENCES}

Aucour, A-M., Booefille, R. \& Hillaire-Marcel, C. 1999. Sources and accumulation rates of organic carbon in an equatorial peat bog (Burundi, East Africa) during Holocene: carbon isotope constraints. Palaeogeography, Palaeoclimatology, Palaeoecology, 150: 179-189.

Bourdon, S., Laggoun-Defarge, F., Disnar, J.R., Maman, O., Guillet, B., Derenne, S. \& Largeau, C. 2000. Organic matter sources and early diagenetic degradation in tropical peaty marsh (Tritrivakely, Madagascar): Implication for environmental reconstruction during the sub-Altantic. Organic Geochemistry, 31: 421-438.

Bowen, R. 1991. Isotopes and climates. Elsevier Applied Science, New York.

Cerling, T.E., Quade, J., Wang, Y. \& Bowman, J.R. 1989. Carbon isotopes in soil and palaesols as ecology and palaeoecology indicators. Nature, 341: 138-139.

Chmura, G.L., Aharon, P., Socki, R.A. \& Abernethy, R. 1987. An inventory of ${ }^{13} \mathrm{C}$ abundances in coastal wetlands of Louisiana, USA: Vegetation and sediments. Oecologia, 74: 264-271.

Choi, Y., Wang, Y., Hsieh Y-P. \& Robinson, L. 2001. Vegetation succession and carbon sequestration in a coastal wetland in northwest Florida: Evidence from carbon isotopes. Global Biogeochemical Cycles, 15: 311-319.

Deines, P. 1980. The isotopic composition of reduced organic carbon. In Handbook of Environmental Isotope Geochemistry, Vol. 1, The Terrestrial Environment, edited by P. Fritz, and J. C. Fontes, pp.
329-406, Elsevier Sci., New York.

DeLauna, R.D. 1986. The use of signature of $\delta 13 \mathrm{C} \mathrm{C}-3$ and $\mathrm{C}-4$ plants in determining past depositional environments in rapidly accreting marshes of Mississippi River deltaic plain, Louisiana, USA. Chemical Geology, 59: 315-320.

Endert F.H. 1932. Het natuurmonument Danau in Bantam. Tectona, 25: 963-986.

Farquhar, G.D., Ehleringer, J.R. \& Hubick, K.T. 1989. Carbon isotope discrimination and photosynthesis. Annual Review of Plant Physiology \& Plant Molecular Biology, 40: 503-537.

Filley, T.R., Freeman, K.H., Bianchi, T.S., Baskaran, M., Colarusso, L.A. \& Hatcher, P.G. 2001. An isotopic biogeochmical assessment of shift in organic matter input to Holocence sediments from Mud lake, Florida. Organic Geochemistry, 32: 1153-1167.

Finnigan. 1995. Finnigan MAT application, Flase report No. $15,{ }^{15} \mathrm{~N} /{ }^{14} \mathrm{~N}$ and ${ }^{13} \mathrm{C} /{ }^{12} \mathrm{C}$ by EA-IRMS: Forensic studies using the ConFlow II interface.

Hedges, J.I. \& Parker, P.L. 1976. Land derived organic matter in surface sediments from the Gulf of Mexico. Geochimica et Cosmochimica Acta, 40: 1019-1029.

Hedges, J.I. \& Ertel, J.R. 1982. Lignin geochemistry of a late quaternary sediment core from lake Washington. Geochimica et Cosmochimica Acta, 46: 1869-1877

Hedges, J.I. \& Ertel, J.R. 1982. Characterization of lignin by capillary gas chromatography of $\mathrm{CuO}$ products. Analytical Chemistry, 54: 174-178.

Hedges, J.I. \& Mann, D.C. 1979. The characterization of plant tissues by their lignin oxidation products. Geochimica et Cosmochimica Acta, 43: 1803-1807.

Herczeg, A.L., Smith, A.K. \& Dighton J.C. 2001. A 120 years record of changes in nitrogen and carbon cycling in lake Alexandria, South Australia: C/N, $\delta^{15} \mathrm{~N}$ and $\delta^{13} \mathrm{C}$ in sediments. Applied Geochemistry, 16: 73-84.

Kaars, S.V.D., Penny, D., Tibby, J., Fluin, J., Dam, R.A.C. \& Suparan, P. 2001. Late quaternary paleoecology, palynology and palaeoliminology of a tropical lowland swamp, Rawa Danau, West Java, Indonesia. Palaeogeography Palaeoclimatology, palaeoecology, 171: 185-212.

Kuder, T. \& Kruge, M.A. 1998. Preservation of biomolecules in sub-fossile plants from raised peat bogs-a potential paleoenvironmental proxy. Organic Geochemistry, 29: 1355-1368.

Macko, S.A., Engel, M.H., Hartly, G., Hatche, P., 
Helleur, R., Jackman, P. \& Silfer, J.A. 1991. Isotopic composition of individual carbohydrates as indicators of early diagenesis of organic matter in peat. Chemical Geology, 93: 147-161.

Meyers, P.A. 1994. Preservation of elemental and isotopic source identification of organic matter. Chemical Geology, 114: 289-302.

Meyers, P.A., Tenzer, G.E., Lebo, M.E. \& Reuter, J.E. 1998. Sedimentary record of sources and accumulation of organic matter in Pyramid Lake, Nevada over the past 1000 years. Limnology Oceanography, 43: 160-169.

Meyers, P.A. 1997. Organic geochemical proxies of paleoceanographic, paleolimonologic and paleoclimatic processes. Organic Geochemistry, 27: 213-250.

Müller, A. \& Voss, M. 1999. The palaeoenvironments of coastal lagoons in the southern Baltic sea II, $\delta^{13} \mathrm{C}$ and $\delta^{15} \mathrm{~N}$, ratio of organic matter - sources and sediments. Palaeogeography Palaeoclimatology, palaeoecology, 145: 17-32.

O’ Leary, M.H. 1988. Carbon isotopes in photosynthesis. Bio Science, 38: 328-336.

Orem, W.H., Colman, S.M. \& Lerch, H.E. 1997. Lignin phenols in sediments of lake Baikal, Siberia: application to paleoenvironmental studies. Organic Geochemistry, 27: 153-172.

Orem, W.H., Neuzil, S.G., Lerch, H.E. \& Cecil, C.B. 1996. Experimental early-stage coalification of a peat sample and peatified wood sample from Indonesia. Organic Geochemistry, 24: 111-125.

Phillips, S. \& Bustin, R.M. 1998. Accumulation of organic rich sediments in a dendritic fluvial/lacustrine mire system at Tasek Bera, Malaysia: implications for coal formation. International Journal of Coal Geology, 36: 31-61.

Rimbaman. 1994. Penelitian Pelestarian Rawa Danau di Kabupaten Serang, Jawa Barat, Pusat Penelitian dan Pengembangan, Geologidan Bandan Perencanaan Pembangunan daerah Propinsi Dati I, Jawa Barat, 40 + appendices.

Rundel, P.W., Ehleringer, J.R. \& Nagy, K.A. 1989. Stable Isotopes in Ecological Research. Springer-Verlag, New York.

Spiker, E.C. \& Hatcher, P.G. 1984. Carbon isotope fractionation of sapropelic organic matter during early diagenesis. Organic Geochemistry, 5: 283-290.

Stewart, G.R., Turnbull, M.H., Schmidt, S. \& Reskine, P.D. $1995 .{ }^{13} \mathrm{C}$ natural abundance in plant communities along a rainfall gradient: a biological integrator of water availability. Australian Journal of plant Physiology, 22: 51-55.

Saldarriaga, J.G. \& West, D.C. 1986. Holocene fires in the north Amazon Basin. Quaternary Research, 26: 358-366.

Sanford, Jr. R.L., Saldarriage, J., Clark, K.E., Uhl, C. \& Herrera, R. 1985. Amazon rainforest fires. Science, 227: 53-55.

Stuijts, I-L.M. 1993. Late Pleistocene and Holocene vegetation of west Java, Indonesia. A A Balkema/ Rotterdam/Brook field, pp. 124-125.

Tareq, S.M., Tanaka, N. \& Ohta, K. 2004. 2004. Biomarker signature in tropical peat: Lignin phenol vegetation index (LPVI) and its implication for reconstructing paleoenvironment. Science of the Total Environment, 324: 91-103.

Tareq, S.M., Tanoue, E., Tsuji, H., Tanaka, N. \& Ohta, K. 2005. Hydrocarbon and elemental carbon signatures in a tropical wetland: Biogeochemical evidence of forest fire and vegetation changes. Chemosphere, 59: 1655-1665.

Van Steenis, C.G.G.J. 1965. Concise plant-geography of Java, In: Flora of Java, 2 (eds. Backer C.A. \& R.C. Bakhuizen van den Brink), pp. 3-72. Groningen; Noordhoff.

Wüst, R.A.J., Hawke, M.I. \& Bustin, R.M. 2001. Comparing maceral ratios from tropical peat lands with assumption from coal studies: do classic coal petrographic interpretation methods have to be discarded? International Journal of Coal Geology, 48: $115-132$.

Wüst, R.A.J. \& Bustin, R.M. 1999. Geological and ecological evolution of Tasek Bera (peninsularMalaysia) wetland basin since the Holocene: evidences of a dynamic system from siliciclastic and organic sediments. Wetlands International-Asia Pacific, Kuala Lumpur, Malaysia.

Yulianto, E., Tsuji, H., Sukapti, S. \& Tanaka, N. 2005. A Holocene pollen and charcoal record from a tropical lowland swamp in Rawa Danau, west Java, Indonesia. Trpoics, 14: 271-281.

Received $17^{\text {th }}$ Oct. 2005 Accepted $26^{\text {th }}$ June 2006 